\title{
POTENSI PEMANFAATAN LAHAN BEKAS TAMBANG YANG DITANAMI RUMPUT GAMBA (Andropogon gayanus) SEBAGAI AREAL PETERNAKAN
}

\author{
E. W. Saragih ${ }^{1)}$ dan S. Bellairs ${ }^{2)}$ \\ 1) Jurusan Peternakan, Fakultas Peternakan, Universitas Papua,Jl. Gunung salju Amban-Manokwari- Papua Barat, 98314 \\ Email: intansaragih@gmail.com \\ 2) Faculty of engineering, health, science, and the environment, Charles Darwin University, Ellengowan Road, Darwin, 0810
}

\begin{abstract}
ABSTRAK
Rumput gamba (Andropogon gayanus) merupakan salah satu tanaman makanan ternak yang memiliki produksi dan palatabilitas yang tinggi. Rumput ini juga dimanfaatkan sebagai tanaman untuk revegetasi di lahan bekas tambang di daerah selatan Australia. Penanaman rumput gamba di lahan bekas tambang atas anjuran peternak karena dianggap rumput ini pakan hijauan yang disukai ternak dengan produksi tinggi. Hal ini juga sesuai tujuan pemanfaatan akhir lahan bekas tambang setelah rehabilitasi yaitu sebagai areal peternakan. Tujuan dari penelitian ini adalah untuk mengetahui potensi pemanfaatan lahan bekas tambang yang ditanami rumput sebagai areal peternakan. Metode penelitian dilakukan dengan cara survei lapangan, Perhitungan produksi hijauan kering didasarkan pada produksi hijauan segar per meter bujursangkar. Pengambilan sampel dilakukan pada areal waste rock dump dan tailing dump pada lahan bekas tambang dan padang penggembalaan alami di dekat lahan bekas tambang. Perhitungan kapasitas tampung areal lahan bekas tambang didasarkan pada rumus. Hasil penelitian ini menunjukkan bahwa rumput gamba dapat tumbuh dengan baik di lahan bekas tambang dengan persentase penutupan tanah berkisar antara 20-60\%. Hal ini menunjukkan pemanfaatan rumput gamba sebagai penutup tanah pada areal lahan bekas tambang cukup efektif. Produksi bahan kering rumput gamba di lahan bekas tambang enam kali lebih tinggi $(2465,30 \pm 414,51 \mathrm{~kg} / \mathrm{ha})$ dibandingkan dengan dengan areal padang penggembalaan alami $(425,46 \pm 202,56 \mathrm{~kg} / \mathrm{ha})$. Kapasitas tampung di lahan bekas tambang juga jauh lebih tinggi (0,5-4 UT/ha) daripada pada padang penggembalaan alami (o,06-1 UT/ha). Tingginya produksi hijauan dan kapasitas tampung menunjukkan bahwa pemanfaatan lahan bekas tambang yang ditanami rumput gamba cukup potensial untuk pengembangan ternak ruminansia.
\end{abstract}

\section{Kata kunci: tambang, gamba, rumput, kapasitas tampung, penutupan tanah}

\section{PENDAHULUAN}

Pemanfaatan lahan bekas tambang sebagai areal peterankan sangat menjanjikan. Ada beberapa alasan mengapa lahan bekas tambang cocok sebagai areal peternakan. Pertama, kondisi tanah yang tidak subur dan terganggu sangat cocok untuk ditanami rumput yang tidak membutuhkan tanah yang subur untuk pertumbuhanya (Maczkowiack et al., 2012) sehingga tidak konflik dengan pemanfaatan lain seperti pertanian. Tanah bekas lahan tambang tidak semua mengandung logam berat yang melampaui standar keamanan pangan. Jika terdapat logam berat yang melampaui standar keamanan pangan maka terlebih dahulu dilakukan remediasi. Sebagai contoh, areal bekas lahan tambang di daerah Kidston Mine di Australia yang sebelumnya merupakan tambang emas telah digunakan sebagai lahan peternakan setelah direhabilitasi lebih dari 25 tahun (Bruce et al., 2003). Hasil penelitian menunjukkan daging ternak sapi yang dipelihara di lahan bekas tambang tersebut aman untuk dikonsumsi. Kedua, penanaman cover crop sebagai pengendali erosi merupakan praktek umum yang dilakukan perusahaan tambang (Mansyur, 2015). Sebagai salah satu cover crop yang umum dipakai adalah rumput yang penanamannya dapat dilakukan dengan mudah dengan menyebar biji rumput. Pertumbuhan rumput yang cepat dibandingkan dengan pohon menjadikan rumput sebagai penutup tanah yang cepat sehingga mengurangi erosi dan longsor. Selain itu rumput akan memperbaiki struktur tanah yang akan menjamin pertumbuhan pohon. Ketiga, lahan bekas tambang biasanya cukup luas dan jauh dari pemukiman penduduk sehingga memenuhi syarat jarak minimum peternakan dengan pemukiman (Mansyur, 2015). Keempat, di beberapa negara seperti Australia dan Inggris, lahan bekas tambang berada di dekat areal peternakan, sehingga lebih memudahkan dalam pengelolaan lahan bekas tambang di masa depan apabila peruntukan lahan setelah tambang diintegrasikan sebagai lahan peternakan. Kelima, bebeberapa areal tambang sebelumnya merupakan lahan peternakan, jadi dianggap lebih cocok untuk mengembalikan penggunaan lahan sebagai lahan peternakan pasca tambang (Bell, 2001). Dengan beberapa alasan di atas, maka dianggap pemanfaatan akhir areal bekas tambang dianggap cocok untuk peternakan.

Pemanfatan lahan bekas tambang sebagai areal 
peternakan telah berkembang sejak beberapa tahun terakhir. Namun pemanfaatan lahan bekas tambang sebagai areal peternakan belum dimanfaatkan secara optimal. Sebagaian usaha peternakan masih tahap uji coba dan skala kecil. Sejak tahun 2013 telah dikembangkan uji coba pemanfaatan lahan bekas tambang sebagai lahan peternakan di beberapa pulau seperti Kalimantan dan Sumatera. Beberapa perusahaan tambang telah mengembangkan areal bekas tambang sebagai lahan peternakan, baik dengan sistem cut and carry, semi intensif maupun dengan sistem penggembalaan secara langsung. Sistem cut and carry menjadikan lahan bekas tambang sebagai sumber hijauan (space utilization) dimana ternaknya dikandangkan. Sebagai contoh, PT. Berau Coal di Kalimantan telah melakukan penanaman hijauan di lahan bekas tambang dan membangun integrated farm system (Berau Coal, 2015). Pada sistem ini sapi dikandangkan dan kotoran sapi dimanfaatkan sebagai sumber energi (listrik dalam kandang) dan limbah sisa kotoran sebagai hasil akhir biogas digunakan sebagai pupuk untuk hijauan. Beberapa perusahaan tambang telah mengelola lahan bekas tambang sebagai areal peternakan di Indonesia. Beberapa perusahaan tambang yang dimanfaatakan antara lain lahan bekas tambang batubara (umumnya di pulau Kalimantan), timah (Kepulauan Bangka Belitung) dan semen (Jawa tengah) dan emas (Nusa Tenggara). Adapun beberapa perusahaan tambang yang telah memanfaatkan lahan bekas tambang sebagai areal peternakan antara lain: PT. Gunung Bayan Pratamacoal Block II, PT. Trubaindo Coal Mining, PT. Kalimantan Prima, dan PT. Andaro Indonesian di Kalimantan Timur. PT. Berau Coal mengembangkan sistem peternakan semi intensif di lahan bekas tambang. Peternakan kambing telah dikembangkan di lahan bekas tambang semen dan penangkaran rusa di lahan bekas tambang emas oleh perusahaan PT. ANTAM di Banten (Mansyur, 2015). Pada areal bekas lahan tambang yang telah direhabilitasi dengan menggunakan rumput sebagai crop cover sangat cocok dijadikan sebagai areal peternakan. Beberapa areal bekas tambang emas di Australia bagian selatan telah direvegetasi dengan menggunakan rumput gamba. Rumput ini memiliki produksi yang cukup tinggi, cocok ditanam dengan kondisi iklim dan tanah di daerah tropis dan disukai ternak sapi. Rumput gamba termasuk rumput potong dan secara morfologi rumput ini mirip rumput raja. Penanaman rumput gamba di areal bekas tambang merupakan anjuran peternak sebagai hasil konsultasi yang dilakukan pihak tambang. Dengan demikian, pemanfaatan akhir dari lahan bekas tambang yang ditanami rumput gamba adalah sebagai areal peternakan. Hingga saat ini, integrasi daerah tambang dengan ranch peternakan yang ada di sekitarnya belum dilakukan. Hal ini disebabkan karena beberapa alasan termasuk belum tersedianya informasi produksi dan penutupan rumput gamba pada lahan tambang. Oleh sebab itu penelitian ini bertujuan untuk melihat potensi areal bekas tambang yang telah direvegetasi dengan rumput gamba sebagai areal peternakan.

\section{MATERI DAN METODE}

Penelitian ini dilakukan di dua areal bekas tambang (Brock Creek dan Moline) dan padang penggembalan alami yang dekat ke masing-masing areal bekas tambang. Kedua lahan bekas tambang ini telah direvegetasi dengan rumput gamba selama kurang lebih 15 tahun. Areal bekas tambang yang digunakan adalah areal waste rock dump dan tailing dam. Terdapat delapan lokasi penelitian yang terdiri dari 4 areal waste rock dump, 1 lokasi tailing dam dan 3 lokasi padang penggembalaan alami. Penelitian ini menggunakan metode deskriptif dengan teknik survei lapang. Pengamatan dilakukan pada penutupan tanah oleh rumput gamba dan produksi rumput gamba pada lahan bekas tambang. Perhitungan kapasitas tampung di lahan bekas tambang didasarkan pada produksi bahan kering rumput gamba. Alat yang digunakan dalam penelitian ini adalah meteran, cuplikan, gunting, timbangann digital kapasitas $50 \mathrm{~kg}$, karung, kamera digital, oven, amplop kertas besar dan alat tulis menulis. Sedangkan bahan yang digunakan adalah rumput gamba. Teknik pengambilan sampel menggunakan transek sepanjang 30 meter pada setiap lokasi penelitian di areal waste rock dump, tailing dump dan padang penggembalaan alami. Tiga transek ditetapkan secara acak pada lokasi yang dapat diakses pada masing-masing lokasi penelitian. Tiga cuplikan diambil secara acak di sepanjang transek sehingga total cuplikan pada masing-masing lokasi penelitian sebanyak 9 cuplikan. Persentase penutupan tanah oleh rumput gamba diamati dan pemotongan rumput gamba pada cuplikan untuk menghitung produksi rumput gamba. Penghitungan kapasitas tampung untuk masing-masing lokasi penelitian didasarkan pada produksi rumput gamba per $\mathrm{m}^{2}$.

Perbedaan penutupan tanah oleh rumput gamba, produksi bahan kering dan kapasitas tampung antar waste rock dump, tailing dump dan padang penggembalaan alami pada dua areal bekas tambang dengan tiga tipe lokasi penelitian dan delapan site pengambilan sampel dianalisis menggunakan General Linear Model (GLM) test. Pada model ini yang menjadi faktor adalah areal bekas tambang (Tambang Brock Creek dan Moline), lokasi penelitian (waste rock dump, tailing dump dan padang penggembalaan alami) di dalam kedua areal bekas tambang dan yang menjadi fixed factor adalah site penelitian. 


\section{HASIL DAN PEMBAHASAN}

\section{Persentase penutupan tanah (\%)}

Penutupan tanah oleh rumput gamba cukup baik di lahan bekas tambang. Hal ini diindikasikan dengan lebih tingginya penutupan tanah oleh rumput gamba di lahan bekas tambang daripada pada areal padang penggembalaan alami. Penutupan tanah berkisar antara $16-66 \%$ di lahan bekas tambang, sedangkan di padang penggembalaan alami berkisar antara 6-19\%. Faktor areal bekas tambang (Tambang 1 dan 2) tidak memberikan pengaruh nyata pada perbedaan penutupan tanah oleh rumput gamba. Namun faktor lokasi penelitian (Waste rock, tailing dump dan padang penggembalaan alami) dan sites menunjukan perbedaan nyata dalam penutupan tanah (GLM, P>0.05). Hal ini berarti penutupan tanah oleh rumput gamba pada areal tailing dam dan waste rock dump lebih tinggi daripada areal padang penggembalaan alami.

Penutupan tanah oleh vegetasi pada areal bekas tambang sangatlah penting. Hal ini berkaitan dengan kemamapuan vegetasi untuk mencegah erosi dan longsor pada lahan bekas tambang. Penutupan vegetasi pada lahan bekas tambang akan mengurangi laju air permukaan tanah dan sebagai penjaring biji-bijian dan bahan-bahan organik lainya akan akan berguna untuk pertumbuhan tanaman dan media tanam untuk tumbuhan baru (Bailey et al. 2012; Ludwig et al. 2004).

Persentase penutupan rumput gamba pada tanah di lahan bekas tambang merupakan salah satu indikator untuk pemanfaatan akhir lahan bekas tambang sebagai areal peternakan. Lahan bekas tambang harus memilki penutupan tanah yang tinggi. Keberadaan ternak pada lahan bekas tambang dapat mempengaruhi kualitas lahan bekas tambang dengan pengurangan penutupan tanah dan biomassa rumput. Daru et al (2012) melaporkan bahwa frekwensi penutupan relatif rumput signal menurun dari $39 \%$ ke 31\% dengan penggembalaan intesif selama 90 hari di lahan bekas tambang. Selanjutnya Silcock (1991) melaporkan bahwa ternak sapi mengurangi biomassa padang rumput di lahan bekas tambang yang ditanami rumput signal di Bowen Basin Queensand. Produksi rumput pada lahan yang tidak digembalakan sebesar 19 ton/ha, sedangkan lahan yang digembalakan sebesar 7,5 ton/ha. Dampak ternak terhadap penutupan tanah dan pengurangan bimassa di lahan bekas tambang harus diminimalisasi. Salah satu cara adalah dengan pemeliharaan ternak ruminansia kecil pada areal dengan persentasi penutupan tanah yang rendah dan ruminansia besar pada lahan dengan persentase penutupan tanah oleh rumput yang tinggi.

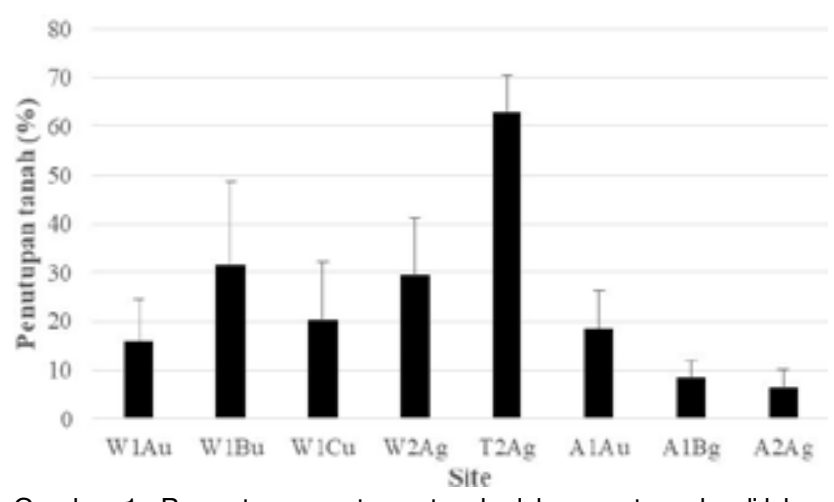

Gambar 1. Persentase penutupan tanah oleh rumput gamba di lahan bekas tambang emas di lokasi waste rock dump, tailing dump di lahan bekas tambang emas dan padang penggembalaan alami. W: waste rock dump, T: tailing dump; A: padang penggembalaan alami, A, B, C: site; U: tanpa penggembalaan; G: dengan penggembalaan.

\section{Produksi Bahan Kering}

Produksi bahan kering (kg/ha) pada lahan bekas tambang cenderung lebih tinggi dibandingkan dengan padang penggembalaan alami. Faktor areal bekas tambang (Tambang 1 dan 2) tidak memberikan pengaruh nyata pada produksi bahan kering. Namun faktor lokasi penelitian (waste rock, tailing dump, dan padang penggembalaan alami) dan sites memberikan pengaruh nyata pada perbedaan dalam produksi bahan kering (GLM, P>0.05). Hal ini berarti terjadi perbedaan produksi bahan kering antara waste rock dump, tailing dump, dan padang penggembalaan alami dan juga antar site. Produksi bahan kering pada lahan bekas tambang berkisar antara 17-43 ton/ha, sedangkan pada padang penggembalaan alami berkisar antara 1-13 ton/ha. Site T2Ag dan W2Ag memiliki produksi lebih tinggi dibandingkan site yang lain. Hal ini mengindikasikan site yang mendapatkan penggembalaan cenderung memiliki produksi bahan kering yang lebih tinggi. Namun perlu diingat bahwa penggembalaan pada site ini sangat rendah ( $<1 \mathrm{UT} / \mathrm{ha})$. Produksi bahan kering pada areal yang digembalakan dan tidak digembalakan pada penelitian ini masih jauh lebih rendah dibandingkan dengan yang dilaporkan Saragih (2017) dengan produksi bahan kering sebesar $343,13 \pm 59,16$ ton/ha di areal yang tidak digembalakan dan sebesar $54,92 \pm 2,87$ ton/ha di areal yang digembalakan.

Perbedaan produksi rumput gamba pada lahan bekas tambang dan padang penggembalaan alami disebabkan beberapa hal. Rumput gamba mendapatkan perlakuan pemupukan pada saat penanaman diawal revegetasi di lahan bekas tambang. Namun informasi dosis pemupukan dan jenis pupuk yang diberikan tidak tersedia. Selain itu, pada masa rehabilitasi, lahan bekas tambang ditutupi dengan lapisan top soil setebal 60 cm dan top soil ini kaya akan bahan organik. Hal 


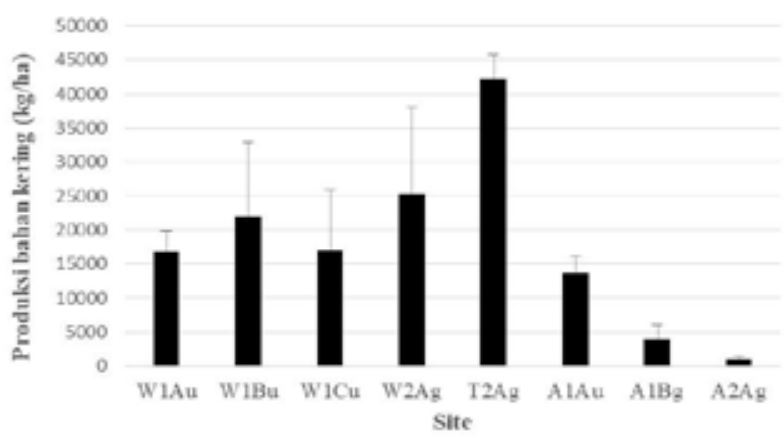

Gambar 2. Produksi bahan kering rumput gamba (kg/ha) di lokasi waste rock dump, tailing dump lahan bekas tambang emas dan padang penggembalaan alami. W: waste rock dump, $\mathrm{T}$ : tailing dump; A: padang penggembalaan alami. A: padang penggembalaan alami, A, B, C: site; U: tanpa penggembalaan; G: dengan penggembalaan.

ini memungkinkan tersedianya cukup unsur hara untuk pertumbuhan rumput gamba di lahan bekas tambang. Rendahnya produksi di padang penggemb alaan alami juga disebabkan karena dua site dari padang penggembalaan alami merupakan daerah ranch dengan tingkat penggembalaan yang cukup tinggi. Meskipun beberapa site (W2Ag dan T2g) di lahan bekas tambang juga digunakan sebagai penggembalaan, namun tingkat penggembalaan cukup rendah. Hal-hal di atas menyebabkan perbedaan produksi rumput gamba di lahan bekas tambang dan padang penggembalaan alami.

\section{Kapasitas Tampung}

Sejalan dengan produksi rumput gamba, tren kapasitas tampung areal bekas tambang lebih tinggi dibandingkan dengan padang penggembalaan alami (Gambar 3). Faktor areal bekas tambang (Tambang 1 dan 2) tidak memberikan pengaruh nyata pada kapasitas tampung. Namun faktor lokasi penelitian (waste rock, tailing dump, dan padang penggembalaan alami) dan sites memberikan pengaruh pada perbedaan nyata dalam produksi bahan kering (GLM, P>0.05). Hal ini berarti tidak terjadi perbedaan kapasitas tampung antar areal bekas lahan tambang. Namun kapasitas tampung berbeda antar waste rock dump, tailing dump, dan padang penggembalaan alami dan antar site. Kapasitas tampung pada site T2Ag memiliki kapasitas tampung yang paling tinggi, dibandingkan site lain di lahan bekas tambang.

Penghitungan kapasitas tampung di lahan bekas tambang di hitung berdasarkan produksi bahan kering rumput gamba per meter persegi. Areal tambang yang memiliki produksi bahan kering tinggi akan tentu memiliki kapasitas tampung yang tinggi pula, demikian juga sebaliknya. Hal ini ditunjukan dengan kecenderungan lebih tinggi kapasitas tampung waste rock dump dan tailing dam dibandingkan dengan padang penggembalaan alami. Kapasitas tampung di lahan bekas tambang berkisar antara 1,5-4 UT/ha, sedangkan di padang penggembalaan alami berkisar antara 0,101,4 UT/ha. Kemampuan lahan bekas tambang untuk mencukupi kebutuhan pakan hijauan yang tinggi menunjukkan bahwa areal ini cukup potensial untuk usaha peternakan.

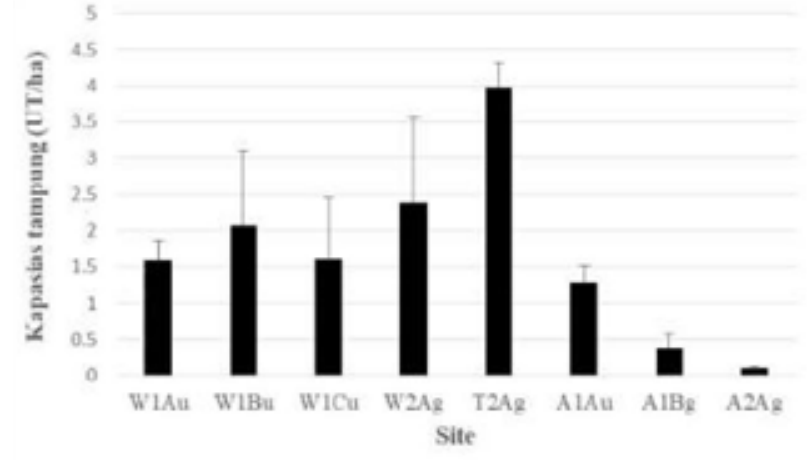

Gambar 3. Kapasitas tampung (UT/ha) di lokasi waste rock dump, tailing dump lahan bekas tambang emas dan padang penggembalaan alami. W: waste rock dump, T: tailing dump; A: padang penggembalaan alami. A: padang penggembalaan alami, A, B, C: site; U: tanpa penggembalaan; G: dengan penggembalaan.

\section{SIMPULAN DAN SARAN}

Penenaman rumput gamba sebagai revegetasi lahan tambang cukup efektif untuk mencegah erosi dan langsor. Hal ini diindikasikan dengan penutupan tanah oleh rumput gamba yang dapat mencapai $60 \%$. Penelitian ini menunjukkan bahwa lahan bekas tambang yang ditanami rumput gamba sangat potensial untuk digunakan sebagai areal perternakan. Hal ini ditunjukan dengan tingginya produksi dan kapasitas tampung per hektar. Namun demikian perlu diperhatikan bahwa penggembalaan pada lahan bekas tambang harus memperhatikan intensitas penggembalaan dan daya tampung untuk menghindari kerusahan areal rehabilitasi akibat penggembalan. Penggembalaan dengan kapasitas tampung rendah atau sistem cut and carry merupakan alternatif sistem penggembalaan yang cocok untuk lahan bekas tambang yang direvegetasi dengan rumput gamba.

\section{UCAPAN TERIMA KASIH}

Pada kesempatan ini penulis mengucapkan terima kasih kepada Crocodile Gold Company Northern Territory Operation yang telah memberikan funding untuk penelitian ini, mengijinkan penulis untuk melakukan penelitian, menyediakan banyak informasi dasar tentang areal bekas tambang dan membantu dalam pelaksanaan penelitian khususnya pengambilan data. 


\section{DAFTAR PUSTAKA}

Bailey, T. G., Davidson, N. J. and Close, D. C. 2012. Understanding the regeneration niche: Microsite attributes and recruitment of eucalypts in dry forests. Forest Ecology and Management 269, 229-238.

Bell, LC 2001, Establishment of native ecosystems after mining - Australian experience across diverse biogeographic zones', Ecological Engineering 17, 179-186.

Bruce, SL, Noller, BN, Grigg, AH, Mullen, BF, Mulligan, DR, Ritchie, PJ, Currey, N and Ng, JC 2003, 'A field study conducted at Kidston Gold Mine, to evaluate the impact of arsenic and zinc from mine tailing to grazing cattle', Toxicology Letters 137, 23-34.

Daru, T. P., Hardjosoewignjo, S., Abdullah, L., Setiadi, Y. and Riyanto. 2012. Grazing pressure of cattle on mixed pastures at coal mine land reclamation. Media Peternakan. 35, 54-59.

Ludwig, J. A, Tongway, D. J., Bastin, G. N. and James, C. D. 2004. Monitoring ecological indicators of rangeland functional integrity and their relation to biodiversity at local to regional scales. Australian Ecology 29, 108-120.

Mansyur, I., 2015. Diskusi pengembangan peternakan di lahan pasca tambang dengan pola silvopastura. Presented at Side Event International Conference of Tropical Biology Theme: Restoring Land and Water Bodies Impacted by Mining Activities to Support Livestock Production. SEAMEO BIOTROP Campus, 12 October 2015. Maczkowiack, R. I., Smith, C. S., Slaughter, G. J., Mulligan, D. R. and Cameron, D. C. 2012. Grazing as a post-mining land use: A conceptual model of the risk factors. Agricultural Systems 109, 76- 89.

PT Berau Coal. 2015. Livestock production on ex-mine sites in Indonesia potential and challenges: Lesson learnt from PT BERAU COAL. Presented at Side Event International Conference of tropical Biology. Theme: Restoring Land and Water Bodies Impacted by Mining Activities to Support Livestock Production. SEAMEO BIOTROP Campus, 12 October 2015.

Saragih, E. W., 2017. Vegetation Development in Gold Mine Rehabilitation in Relation to Cattle Grazing in the Northern Territory, Australia. Charles Darwin University. Thesis.

Silcock, R. G. 1991. Pastures, trees and shrubs for rehabilitating mines in Queensland. Impediments to their use on open cut coal and alluvial mines in 1990. Occasional Paper (1), AMAEE Foundation QDPI Brisbane. 